УДК 341.64

DOI https://doi.org/10.32849/2663-5313/2020.5.60

Олена Поліванова, канд. юрид.наук,

доцент кафедри міжнародного права і порівняльного правознавства Київського університету права Начіональної академї наук України

\title{
Дар'я Третьякова,
}

здобувачка вищої освіти

Київського університету права Національної академії наук України

\section{ЕФЕКТИВНИЙ КОНТРОЛЬ ДЕРЖАВИ ПОЗА МЕЖАМИ ЇЇ ТЕРИТОРІАЛЬНОЇ ЮРИСДИКЦІї: ПІДСТАВИ ПРИТЯГНЕННЯ ДО ВІДПОВІДАЛЬНОСТІ ЗА ПОРУШЕННЯ ПРАВ ЛЮДИНИ У ПРАКТИЦІ ЄСПЛ}

У статті досліджується практика Європейського суду з прав людини щодо притягнення до відповідальності держави за порушення Конвениї про захист прав людини і основоположних свобод 1950 року поза ї територіальними межами, а саме на території іншої держави-сторони Конвенції, шляхом встановлення для досягнення иілей ст. 1 Конвениії ї юрисдикиії внаслідок здійснення нею ефективного контролю над такою територією. Окрему увагу зосереджено на розглянутих Судом справах (інічійованих як у рамках ст. 33, так і в межах ст. 34 Конвениії), які стали наслідком створення (за військової, економічної та політичної підтримки держави-сторони Конвениіі) на міжнародно визнаній території іншої держави-сторони (Кіпру, Молдови, Азербайджану) невизнаного міжнародним співтовариством суверенного державного утворення: щодо відповідальності Туреччини за порушення Конвениї на Північному Кіпрі, Росії за порушення, які відбулися в Придністровї, і Вірменії за порушення Конвениї у Нагірному Карабасі.

Аналіз практики Суду щодо притягнення до відповідальності держави-сторони Конвениії через встановлення для досягнення иілей ст. 1 Конвениї̈ ї юрисдикиї на міжнародно визнаній території іншої держави-сторони Конвениії дав змогу виокремити низку підстав, за наявності яких перша може бути притягнена у Суді до відповідальності за порушення прав людини на цій території. Ключовою підставою встановлення юрисдикиї держави за дії поза межами ї територіальної юрисдикиї $\epsilon$ доведення факту здійснення нею ефективного контролю над іноземною територією - внаслідок військових (законних чи незаконних) дій: прямого ефективного контролю - через збройні сили такої держави, чи непрямого - через підпорядковану ій місиеву адміністраиію. Встановлення факту тако$2 о$ контролю над територією покладає на державу, яка його здійснює, відповідальність як за дії ї̈ солдатів чи посадових осіб у иій місиевості, так і за політику та дії місиевої адміністраиії і виключає необхідність доведення у Суді факту здійснення детального контролю політики та дій останньої. У разі встановлення факту ефективного контролю Суд ураховує кількість військовослужбовиів, розміщених державою на відповідній території, $і$ ступінь, у якому військова, економічна чи політична підтримка підпорядкованих контролюючій державі місцевих адміністрачій надає їм вплив і контроль над регіоном.

Доведення факту окупаиії міжнародно визнаної територіїдержави-сторони Конвениії збройними силами іншої держави-сторони Конвенції і перешкоджання ними реалізачії прав і свобод, закріплених Конвениією, може бути підставою для визнання юрисдикиї в значенні ст. 1 Конвениї за останньою. Повний і виключний контроль окупованої території державою може бути підтверджений фактом диктування нею ходу подій у ї̈ межах. Якщо місцева адміністрація на такій території виживає внаслідок військової, політичної, фінансової чи іншої підтримки іноземної держави, «юрисдикиія» иієі держави на чій території поширюється на забезпечення всього спектра матеріальних прав, викладених у Конвенції та тих ї̈ протоколах, які вона ратифікувала, $i$, відповідно, вона несе відповідальність за їх порушення. Тісні відносини держави-сторони Конвениії із не визнаним міжнародною спільнотою суб'єктом після факту надання нею підтримки щодо його створення можуть бути прирівняні до політичної, фінансової та економічної підтримки сепаратистського режиму. Залучення (иляхом військової присутності та надання військових матеріалів та порад) держави-сторони Конвениії до 
ранніх стадій конфлікту у іншій державі-стороні Конвениї (виходячи з ї доповідей та публічних заяв), що призвело до створення в ї̈ межах не визнаного міжнародною спільнотою суб'єкта у зв'язиі із наданням істотної політичної, військової та фінансової підтримки місцевій адміністрації такого суб'єкта, за рахунок яких остання і виживала, вказують на наявність ефективного контролю такої держави над ї̈ територією.

Ключові слова: Європейський суд з прав людини, Конвенція, порушення прав людини, територія, юрисдикція, відповідальність, Лоізіду, Кіпр проти Туреччини, Гюзельюртлу, Ілашку, Івантош, Катан, Мозер, Чігаров.

Постановка проблеми. Європейський суд 3 прав людини (далі - ЄСПЛ, Суд) міжнародний європейський судовий орган, покликаний забезпечувати дотримання Конвенції про захист прав людини і основоположних свобод 1950 року (далі - СКПЛ, Конвенція) та протоколів до неї їхніми державами-сторонами [16]. Своєю чергою відповідно до ст. 1 держави-сторони Конвенції зобов’язуються гарантувати закріплені ними права і свободи кожному, хто перебуває під їхньою юрисдикцією [16]. Саме здійснення юрисдикції $є$ необхідною умовою притягнення держави-сторони Конвенції до відповідальності за вчинені нею дії чи бездіяльність, які породили твердження про порушення прав та свобод, викладених у Конвенції («Катан та інші проти Республіки Молдова та Росіï», § 103) [10].

Практика ЄСПЛ підтвердила, що юрисдикція держави за змістом ст. 1 Конвенції $€$ переважно територіальною («Серінг проти Сполученого Королівства» (§ 86) [30], «Банкович та інші проти Бельгії та інших» (§§ 61, 67) [7], «Ілашку та інші проти Молдови і Росії» (§ 312) [18], «Аль-Скейні та інші проти Сполученого Королівства» (§ 131) [5]) і реалізується на всій території держави (§ 139 «Асанідзе проти Грузії [6], § 312 «ллашку та інші проти Молдови і Росії [18]). Тому інші підстави здійснення державою-стороною Конвенції юрисдикції поза їі територіальними межами (як-от дії органів держав-сторін Конвенції, вчинені (або які призводять до наслідків) поза їхньою територією) є винятковими і вимагають спеціального обгрунтування в конкретних обставинах кожної справи (§§ 61, 67, 71 рішення у справі Банкович [7], § 104 рішення у справі Катан [10] та § 131 рішення у справі АльСкейні [5]). Одна із таких виняткових підстав, за якої може виникнути питання щодо юрисдикції держави-сторони Конвенції поза іiї територіальними межами, - фактичне здійснення нею контролю над іноземною територією (ratione loci) [27, с. 12]. Що стосується принципу юрисдикції «ефективного контролю» над конкретною територією, то слід зазначити, що всі справи, які досі розглядав ССПЛ під цим кутом зору, стосувались контролю території держави-сторони Кон- венції іншою державою-стороною в умовах збройного конфлікту (під час зазначеного конфлікту чи після припинення бойових дій) (§ 45) [27, с. 16]. У таких ситуаціях виникає питання «юрисдикції», коли держава втрачає ефективний контроль над усією або частиною своєї міжнародно визнаної території. При цьому можуть виникнути питання щодо юрисдикції і відповідальності держави двох видів. Якщо держава посягає на територіальну та політичну цілісність іншої держави, скарги, подані до Суду, можуть бути спрямовані як проти «активної» договірної держави, яка здійснює свої повноваження за межами власної території (у формах повної або часткової військової окупації іншої держави, підтримки повстання чи громадянської війни в іншій державі або встановлення (надання допомоги із встановлення) на території іншої держави сепаратистського режиму у формі суб'єкта, який не визнається суверенною державою міжнародною спільнотою), так і проти «пасивної» договірної держави, щодо якої здійснюється будь-яка із вищезазначених дій [27, с. 16] (у кожному з двох випадків держава-відповідач несе різну відповідальність). У цій статті розглядаються питання юрисдикції і відповідальності «активної» держави; при цьому увагу зосереджено на одній із категорій справ, розглянутих ЄСПЛ у цьому зв'язку, - справи, які стали наслідком створення (за військової, економічної та політичної підтримки держави-сторони Конвенції) на міжнародно визнаній території іншої держави-сторони ЄКПЛ (Кіпру, Молдови, Азербайджану) суб'єкта, який не визнається суверенною державою міжнародним співтовариством [27, с. 17-18]. Суд розглядав таку ситуацію у трьох різних історико-політичних контекстах [27, с. 20]: встановлюючи відповідальність Туреччини за порушення Конвенції на Північному Кіпрі [12; 17; 20; 21; 22], Росії за порушення, які відбулися в Придністров”ї [10; 18; 19; 26], і Вірменії за порушення Конвенції у Нагірному Карабасі [11]. Разом із тим, як показує практика ЄСПЛ, підстави притягнення держави до відповідальності за порушення прав людини, закріплених Конвенцією, через поширення іï юрисдикції на дії, які мали місце на міжнародно визнаній території 
іншої держави напряму залежать від фактів кожної конкретної справи, а тому нині потребують вивчення і узагальнення, зважаючи на гостроту обговорюваного питання.

Аналіз останніх досліджень і публікацій. Окремим питанням юрисдикції держав, встановлення приналежності їм дій чи бездіяльності, вчинених поза межами їхньої територіальної юрисдикції, відповідальності держав за порушення прав людини приділялася увага у працях як українських (Є. Герасименка [1], Т. Горбачевської [2], О. Плотнікова [3]), так і зарубіжних науковців (Т. Абдель-Момен [4], Д. Бадзяновська [8], М. Датвілер [14], Т. Ітвел [15], Л. Кафліш [9], Р. Лоусон [13], М. Міланович [23, 24], С. Міллер [25], М. Хеєр [13]). Однак аналізу практики ЄСПЛ щодо визначення підстав, за наявності яких держава-сторона Конвенції може бути притягнена до відповідальності за порушення Конвенції на території іншої держави-сторони Конвенції шляхом встановлення для досягнення цілей ст. 1 Конвенції юрисдикції першої внаслідок здійснення нею ефективного контролю над такою територією, належної уваги приділено не було. Саме тому це дослідження, зосереджуючи увагу на розглянутих ЄСПЛ справах у цьому зв'язку, ініційованих як у рамках ст. 33, так і в межах ст. 34 Конвенції, є спробою окреслити такі підстави i, таким чином, заповнити відповідну прогалину української науки європейського права.

Метою статті є аналіз практики ЄСПЛ щодо притягнення до відповідальності держави за порушення СКПЛ поза їі територіальними межами, а саме на території іншої держави-сторони Конвенції шляхом встановлення для досягнення цілей ст. 1 Конвенції її юрисдикції внаслідок здійснення нею ефективного контролю над такою територією.

Виклад основного матеріалу дослідження. 24 серпня 1960 року Рада Безпеки ООН одностайно прийнятою резолюцією рекомендувала Кіпр до вступу в ООН [28], а 1 жовтня того ж року Кіпр набув статусу незалежної держави. Разом із тим перша серія справ, що розглянута ЄСПЛ і пов'язана зі створенням (за військової, економічної та політичної підтримки держави-сторони Конвенції) однією державоюстороною Конвенції на міжнародно визнаній території іншої держави-сторони СКПЛ суб'єкта, який не визнається суверенною державою міжнародним співтовариством, і визначенням держави, у юрисдикції якої (в значенні ст. 1 Конвенції) перебували оскаржувані дії, що призвели до порушення прав людини за ЄКПЛ, стосувалася ситуації, яка склалася саме на півночі Кіпру з моменту, коли Туреччина проводила там військові дії в липні та серпні 1974 року і триваючого поділу території Кіпру. Піком поділу Кіпру було проголошення у листопаді 1983 року «Турецької Республіки Північний Кіпр» (далі - «ТРПК») з подальшим прийняттям «Конституції ТРПК» у травні 1985 року (із рішення у справі «Кіпр проти Туреччини», § 14) [12]. Турецька військова присутність на півночі Кіпру у той самий час була описана у рішенні у справі «Лоізіду проти Туреччини» 1996 року (§§ 16-17) [21] (далі Лоізіду), у якій заявниця, грецька кіпріотка, скаржилася на позбавлення іï доступу до належної їй власності на півночі Кіпру. Пані Лоізіду жила та володіла землею на півночі Кіпру до турецької окупації місцевості. Вона подала позов проти Туреччини, стверджуючи, що все ще є законною власницею землі, незважаючи на законодавчі положення, встановлені конституцією «ТРПК». Вона заявила, що турецькі сили заважали і продовжували заважати їй повернутися у Кіренію (північний Кіпр) і мирно користуватися іiі власністю (§ 12) [21]. Вона стверджувала, що при цьому мали місце порушення ст. 1 Протоколу № 1 та статті 8 Конвенції (§ 28) [21].

Першим юридичним питанням на вирішенні Суду було заперечення ratione temporis, висловлене турецьким урядом. Оскільки декларація Туреччини 1990 року, подана відповідно до ст. 46 Конвенції, виключала юрисдикцію ЄСПЛ щодо фактів, які відбулися до дати здачі іiі на зберігання, заявниця мала довести, що передбачувані порушення не обмежувалися періодом до 1990 року, а продовжували тривати і після. Якщо вони продовжувалися, пані Лоізіду все ж залишалася законною власницею землі. Оскільки міжнародна спільнота оголосила «ТРПК» незаконним режимом, Суд вирішив, що не може визнати Конституцію «ТРПК» 1985 року юридично чинною. Отже, положення іiї ст. 159 про експропріацію майна, залишеного біженцем, не могли призвести до втрати заявницею права власності на їі майно, і заперечення відповідача ratione temporis було відкинуте (§§ 39-47) [21].

Другим питанням, яке вирішив ЄСПЛ, було, чи могла Туреччина бути визнаною відповідальною за передбачувані порушення (§ 49) [21]. Суд постановив, що відповідно до ст. 1 Конвенції поняття «юрисдикція» не обмежується національною територією держави-сторони Конвенції (§ 52) [21]. Відповідно, відповідальність держав-сторін Конвенції може бути пов'язана 3 діями та бездіяльністю їхніх органів влади, які 
спричинюють наслідки поза їхньою територією. Суд визнав, відповідно до принципів міжнародного права щодо відповідальності держав, що відповідальність держави може виникнути і тоді, коли внаслідок військових дій - законних чи незаконних - вона здійснює ефективний контроль над територією за межами своєї національної території. Зобов'язання забезпечити на такій території права та свободи, викладені в Конвенції, випливає з факту такого контролю, незалежно від того, здійснюватиметься він безпосередньо через збройні сили такої держави чи через підпорядковану їй місцеву адміністрацію (§ 62) [22, С. 23-24]. ЄСПЛ зазначив, що втрата заявницею контролю над їі майном пов'язана з окупацією турецькими військами північної частини Кіпру та створенням там «ТРПК», а також із тим, що заявниця була позбавлена доступу до її власності турецькими військами. Таким чином, оскаржені дії могли підпадати під турецьку «юрисдикцію» у значенні ст. 1 Конвенції (§§ 63-64) [22, с. 24]. У рішенні по суті тієї самої справи Суд, розглядаючи «приналежність» передбачуваних порушень Туреччині, визнав, що не було необхідності встановлювати, чи ця держава здійснювала детальний контроль над політикою та діями влади «ТРПК», оскільки було очевидно 3 великої кількості військ (за весь період окупації у північному Кіпрі дислокувалося понад 30000 військових (§ 16) [21]), які виконували активні обов'язки на спірній території, що турецька армія здійснювала ефективний повний контроль над тією частиною острова; такий контроль поклав на Туреччину відповідальність за політику та дії «ТРПК». Отже, особи, які постраждали від цих політики та дій, потрапили під «юрисдикцію» Туреччини, і ймовірні порушення були, відповідно, «приналежні» цій державі (§§ 52-56) [21]

У міждержавній справі «Кіпр проти Туреччини», направленій до Суду відповідно до положень, що застосовувались до набуття чинності Протоколом № 11 до Конвенції, урядом Республіки Кіпр 30 серпня 1999 року та Свропейською комісією з прав людини (далі - Комісія) 11 вересня 1999 року, Урядзаявник просив Суд прийняти рішення, що держава-відповідач несе відповідальність за порушення ст.ст. 1, 2, 3, 4, 5, 6, 8, 9, 10, 11, 13, 14, 17 та 18 Конвенції та ст.ст. 1 та 2 Протоколу № 1 (§ 18) [12]. Уряд-відповідач заперечував відповідальність Туреччини відповідно до Конвенції за звинувачення, викладені в заяві. У своїх поданнях до Комісії Уряд-відповідач стверджував, що оскаржувані дії та бездіяльність можуть бути приписані виключно «ТРПК» - незалежній державі, створеній турецько-кіпрською громадою, використовуючи її право на самовизначення та володіючи виключним контролем та повноваженнями над територією, що знаходиться на північ від буферної зони ООН Уряд-відповідач у зв'язку з цим висловився 3 приводу того, що Суд у рішенні Лоізіду помилково зробив висновок, що «ТРПК» $€$ підпорядкованою місцевою адміністрацією, за дії та бездіяльність якої за ст. 1 Конвенції несе відповідальність Туреччина (§ 69) [12].

Уряд-заявник стверджував перед Судом, що «ТРПК» $є$ незаконним утворенням згідно з міжнародним правом, оскільки воно зобов'язане своїм існуванням незаконному акту вторгнення держави-відповідача у північну частину Кіпру в 1974 році та постійній незаконній окупації цієї частини Кіпру з тих пір. Спроба держави-респондента посилити поділ Кіпру шляхом проголошення створення «ТРПК» у 1983 році була рішуче засуджена міжнародною спільнотою, про що свідчить прийняття Радою Безпеки ООН резолюцій 541 (1983) та 550 (1984) і Комітетом міністрів Ради Свропи резолюції від 24 листопада 1983 року (§ 70) [12]. Уряд заявника підкреслив, що навіть, якщо Туреччина не мала юридичного права на північний Кіпр за міжнародним правом, Туреччина несе юридичну відповідальність за цю територію в рамках Конвенції, враховуючи, що вона здійснювала повний військовий та економічний контроль над цією територією. Цей повний і виключний контроль окупованої території підтверджувався неспростовними доказами влади Туреччини диктувати хід подій у її межах. За твердженням уряду-заявника, держава-сторона Конвенції не може шляхом делегування повноважень підлеглому та незаконному управлінню уникнути своєї відповідальності за порушення Конвенції і міжнародного права взагалі. Проголосити протилежне в контексті ситуації північного Кіпру означало б породити велику прогалину в системі захисту прав людини i, справді, призвело б до непридатності системи Конвенції (§ 71) [12]. Отже, в «Кіпр проти Туреччини» Суд повторив свій загальний висновок у Лоізіду, що Туреччина на практиці здійснювала повний контроль на півночі Кіпру завдяки своїй військовій присутності на місцях; отже, за політику та діі органів «ТРПК» вона набула відповідальності за Конвенцією. Суд підкреслив, що відповідальність Туреччини відповідно до Конвенції не може обмежуватися діями їі власних солдатів чи службових осіб на півночі Кіпру, але також повинна виникати виходячи із дій місцевої адміністрації, яка виживала внаслідок турецької військової 
та іншої підтримки. Слід вважати, що «юрисдикція» Туреччини поширюється на забезпечення всього спектра матеріальних прав викладених у Конвенції та тих додаткових протоколах, які вона ратифікувала, і порушення цих прав були належні їй (§§ 76-77).

У справі «Гюзельюртлу та інші проти Кіпру та Туреччини» стосовно вбивств кількох колишніх жителів «ТРПК» на територі Республіки Кіпр та розслідувань, які проводилися щодо цих фактів владою «ТРПК», Суд зазначив, що міжнародна спільнота вважає Туреччину окупантом північної частини Кіпру і не визнає в рамках міжнародного права «ТРПК» державою. Для цілей Конвенції Північний Кіпр перебував під ефективним контролем Туреччини. Підозрювані у вбивствах втекли до «ТРПК», що, як наслідок, завадило Республіці Кіпр вести власне кримінальне розслідування стосовно цих підозрюваних, а отже, виконувати свої зобов'язання за Конвенцією (§ 193) [17].

Друга серія справ стосувалася відповідальності Росії за діяння, вчинені в «Молдавській Республіці Придністров'я», утвореній на молдавській території. У справі «Ілашку та інші проти Молдови та Росії» (далі - Ілашку) заявники, серед яких були особи, засуджені до страти та тяжких тюремних вироків «верховним судом» цього суб'єкта, скаржилися на низку порушень їхніх основних прав, які, на їхню думку, здійснювала Росія. Суд зазначив, що в 1991-1992 роках сили колишньої 14-ї армі (яка належала СРСР і тепер - Росії), що розміщувалися в Придністров'ї, воювали на стороні придністровських сепаратистських сил. Велика кількість зброї з арсеналу 14-ї армії була добровільно передана сепаратистам, які, більше того, змогли забезпечити подальше озброєння, не зустрівши опору 3 боку російських військових. Крім того, протягом протистоянь молдавської влади та придністровських сепаратистів російські лідери робили політичні заяви на підтримку сепаратистської влади. Навіть після угоди про припинення вогню Росія продовжувала надавати військову, політичну та економічну підтримку сепаратистському режиму, тим самим дозволяючи йому виживати шляхом зміцнення себе та набуття певної кількості автономії від Молдови. На думку Суду, всі дії, вчинені проти заявників російськими військовими органами, включаючи передачу їх сепаратистському режиму, не визнаному міжнародною спільнотою, в контексті співпраці між російською владою та цим неправомірним режимом, створили відповідальність за наслідки дій цього режиму. Усі матеріали справи свідчили про те, що Придністров- ський регіон залишався під ефективним контролем Росії або, принаймні, під його вирішальним впливом, і в будь-якому разі він виживав завдяки військовій, економічній, фінансовій та політичній підтримці з боку Росії як до, так і після ратифікації Конвенції. За таких обставин заявники перебували в межах «юрисдикції» Росії, внаслідок чого на неї покладається відповідальність стосовно оскаржуваних дій (§§ 377-394) [18]

Висновок щодо відповідальності Росії у Придністров'ї було підтверджено у справах «Івантош та інші проти Молдови та Росії» [19], «Катан та інші проти Республіки Молдова та Росії» [10] та «Мозер проти Республіки Молдова та Росії» [26]. Зокрема, у справі «Івантош та інші проти Молдови та Росії (далі - Івантош) щодо тривалого затримання двох із чотирьох заявників у справі «Ілашку та інші проти Молдови та Росії» (після і попри винесення рішення Великою палатою Суду у цій справі) ЄСПЛ прагнув встановити, чи змінилася російська політика підтримки придністровського сепаратистського режиму між 2004 та 2007 роками, датою звільнення заявників. Він зазначав, що Росія продовжувала користуватися тісними стосунками 3 «Молдавською Республікою Придністров'я», що прирівнюється до політичної, фінансової та економічної підтримки сепаратистського режиму. Більше того, Суд встановив, що російська армія (війська, техніка та боєприпаси) на дату звільнення заявників все ще перебувала на території Молдови, порушуючи молдавське законодавство i взяті на себе Російською Федерацією зобов'язання щодо повного самоусунення. Тому заявники потрапили під «юрисдикцію» Росії для цілей ст. 1 Конвенції (§§ 116-120) [19].

У справі «Катан та інші проти Республіки Молдова та Росії» щодо скарги, поданої дітьми та батьками молдавської громади в Придністров'ї щодо наслідків мовної політики, прийнятої у 1992 та 1994 роках сепаратистським режимом, що забороняв використовувати латинський алфавіт у школах, а також наступні заходи щодо здійснення цієї політики. Повторивши свої висновки, попередньо вже викладені в Ілашку і Івантош, Суд зазначив, що Росія продовжувала надавати військову, економічну та політичну підтримку придністровським сепаратистам (поставки газу, виплати пенсій тощо). Оспорювані факти, таким чином, потрапляли під юрисдикцію Росії, навіть якщо жодні російські агенти не брали безпосередньої участі у заходах, прийнятих проти шкіл заявників (§§ 116-123) [10].

У справі «Мозер проти Республіки Молдова та Росії» (щодо утримання чоловіка, 
підозрюваного в шахрайстві, за постановою судів «Молдавської Республіки Придністров'я»), ЄСПЛ, враховуючи відсутність будь-якої відповідної нової протилежної інформації, підтвердив, що його висновок, висловлений у всіх вищезазначених справах щодо юрисдикції Росії, залишився чинним і стосовно періоду, що розглядається у цій справі [26].

Третя ситуація, яку розглядав Суд, стосувалася відповідальності Вірменії за діяння, вчинені у «Нагірно-Карабаській Республіці» (далі - «НКР»), створеній у районі Азербайджану. На час розпаду Радянського Союзу в грудні 1991 року Нагірно-Карабаська автономна область (далі - НКАО) була автономною провінцією, що перебувала в складі Азербайджанської Радянської Соціалістичної Республіки (Азербайджанської РСР). У НКАО та Вірменської Радянської Соціалістичної Республіки (Вірменської РСР), розділеної територією Азербайджану, не було спільного кордону. У 1988 році в цьому регіоні спалахнули збройні бойові дії. У вересні 1991 року, невдовзі після того, як Азербайджан проголосив незалежність від Радянського Союзу, Рада НКАО оголосила про заснування «НКР», що включала НКАО та Шаумянівський район Азербайджану. Після референдуму, який відбувся в грудні 1991 року (і бойкотувався його азербайджанським населенням) і на якому 99,9\% виборців виступили за відокремлення «НКР», остання підтвердила свою незалежність від Азербайджану в січні 1992 року. Після цього конфлікт поступово переріс у повномасштабну війну. До кінця 1993 року етнічні вірменські війська отримали контроль майже над усією територією колишнього НКАО та семи сусідніми азербайджанськими областями. У травні 1994 року воюючі підписали угоду про припинення вогню, яка діє і досі. Самопроголошена незалежність «НКР» не була визнана жодною державою чи міжнародною організацією (§§ 12-31 рішення у справі «Чігаров та інші проти Вірменії» [11], §§ 14-28 рішення у справі «Саргсян проти Азербайджану» [29]).

У справі «Чірагов та інші проти Вірменії» заявники, азербайджанські курди 3 району Лачин (який є частиною Азербайджану і відокремлює Нагірний Карабах від Вірменіï), скаржилися на їхню неможливість мати доступ до своїх будинків та майна, оскільки були змушені залишити район через збройний конфлікт між двома державами. Відповідно до ст. 1 Конвенції Суд урахував цілу серію доповідей та публічних заяв, особливо тодішніх та колишніх членів уряду Вірменії, і дійшов висновку, що Вірменія завдяки своїй військовій присутності та наданню військових матеріалів та порад була залучена до конфлікту в Нагірному Карабасі на його ранніх стадіях. На думку Суду, така військова підтримка була вирішальною для контролю над територіями, про які йдеться; крім того, з фактів справи було очевидно, що Вірменія надавала істотну політичну та фінансову підтримку «НКР». Більше того, мешканці «НКР» повинні були отримати паспорт Вірменії для виїзду за кордон. Суд встановив, що Вірменія та «НКР» були дуже інтегровані практично у всіх важливих питаннях, а також те, що «НКР» та її адміністрація вижили завдяки військовій, політичній, фінансовій та іншій підтримці Вірменії, яка, відповідно, здійснювала ефективний контроль над Нагірним Карабахом та прилеглими територіями. Тому ймовірні факти мали місце під юрисдикцією Вірменії (§§ 169-186) [11].

\section{Висновки}

Аналіз практики ССПЛ щодо притягнення до відповідальності держави-сторони Конвенції через встановлення її юрисдикції над міжнародно визнаною територією іншої держави-сторони Конвенції дав змогу виокремити низку підстав, за наявності яких перша може бути притягнена у ССПЛ до відповідальності за порушення прав людини на цій території. Встановлюючи юрисдикцію і відповідальність «активної» держави, Суд насамперед має встановити, чи передбачувані факти підпадають під її «юрисдикцію» в цілях ст. 1 Конвенції. Ключовою ж підставою встановлення юрисдикції держави за дії поза межами іï національної території є доведення факту здійснення нею ефективного контролю над іноземною територією - внаслідок військових (законних чи незаконних) дій: прямого ефективного контролю - через збройні сили такої держави, чи непрямого - через підпорядковану їй місцеву адміністрацію. Зобов'язання забезпечити на такій території права та свободи людини, включені у Конвенцію, випливає 3 факту такого контролю, незалежно від того, здійснюється він безпосередньо через власні збройні сили держави-сторони ЄКПЛ або через підпорядковану їй місцеву адміністрацію.

Там, де встановлено факт такого контролю над територією, не потрібно визначати, чи здійснює держава-сторона ЄКПЛ детальний контроль за політикою та діями підпорядкованої місцевої адміністрації. Той факт, що місцева адміністрація виживає внаслідок військової та іншої підтримки цієї держави, тягне за собою відповідальність цієї держави 
за свою політику та дії. Контролююча держава несе відповідальність згідно зі ст. 1 Конвенції забезпечити в межах підконтрольної ій території весь спектр матеріальних прав, викладених у Конвенції та тих додаткових протоколах до неї, які вона ратифікувала. Така держава буде нести відповідальність за будь-які порушення цих прав. Більше того, якщо держава-сторона Конвенції здійснюе повний контроль над територією поза іï власними територіальними межами, іiі відповідальність не обмежується діями їі солдатів чи посадових осіб у цій місцевості, але також поширюється на дії місцевої адміністрації, яка виживає там через військову чи іншу підтримку контролюючої держави.

Питання, чи справді держава-сторона ЄКПЛ здійснює ефективний контроль над територією за іï власними територіальними межами, є питанням факту. Прагнучи відповісти на нього, Суд насамперед враховує такі два критерії: кількість військовослужбовців, розміщених державою на відповідній території (критерій, якому Суд надавав досі найбільшого значення), і ступінь, у якому військова, економічна чи політична підтримка підпорядкованих контролюючій державі місцевих адміністрацій надає їм вплив і контроль над регіоном.

Доведення факту окупації міжнародно визнаної території держави-сторони Конвенції збройними силами іншої держависторони Конвенції і перешкоджання ними реалізації прав і свобод, закріплених Конвенцією, може бути підставою для визнання юрисдикції в значенні ст. 1 Конвенції за останньою. Повний і виключний контроль окупованої території державою може бути підтверджений фактом диктування нею ходу подій у іï межах. Якщо місцева адміністрація на такій території виживає внаслідок військової, політичної, фінансової чи іншої підтримки іноземної держави, «юрисдикція» цієї держави на цій території поширюється на забезпечення всього спектра матеріальних прав, викладених у Конвенції та тих додаткових протоколах, які вона ратифікувала, i, відповідно, вона несе відповідальність за їхне порушення. Тісні відносини держави-сторони Конвенції із не визнаним міжнародною спільнотою суб'єктом після факту надання нею підтримки щодо його створення можуть бути прирівняні до політичної, фінансової та економічної підтримки сепаратистського режиму. Залучення (шляхом військової присутності та надання військових матеріалів та порад) держави-сторони Конвенції до ранніх стадій конфлікту у іншій державістороні Конвенції (виходячи з ії доповідей та публічних заяв), що призвело до ство- рення в її межах не визнаного міжнародною спільнотою суб'єкта у зв'язці із наданням істотної політичної, військової та фінансової підтримки місцевій адміністрації такого суб'єкта, за рахунок яких остання і виживала, вказують на наявність ефективного контролю такої держави над іï територією.

Вагомий вплив на формування думки Суду під час прийняття рішення у таких справах, на наш погляд, також має ставлення міжнародного співтовариства до факту створення на міжнародно визнаній території держави-сторони Конвенції окремого суб’єкта, який не визнається суверенною державою, а також до факту причетності (прямої чи опосередкованої) до цього іншої держависторони Конвенції.

\section{Список використаних джерел:}

1. Герасименко $€$. Щодо «ефективного контролю» і неефективної критики. Українська правда. 17 лютого 2017. URL: https://www.pravda. com.ua/columns/2017/02/17/7135511/ (дата звернення: 27.04.2020)

2. Горбачевська Т. Захист прав людини у збройному конфлікті між Україною та Росією: питання юрисдикції у світлі практики Європейського суду з прав людини. Зобов'язання, що випливають з фактичного або загального контролю держави-агресора (Частина I). Human Rights in Ukraine. Website of the Kharkiv Human Rights Protection Group. URL: http://khpg.org/en/index. php?id=1562658156 (дата звернення: 27.04.2020).

3. Плотніков О.В. Юрисдикція Європейського суду з прав людини щодо окупованих територій. Academia. URL: https://www.academia.edu /8403194/\%D0\%AE\%D1\%80\%D0\%B8\%D1\%81\% D0\%B $\%$ D0\%B8\%D0\%BA\%D1\%86\%D1\% ～(дата звернення: 27.04.2020).

4. Abdel-Monem T. How Far Do the Lawless Areas of Europe Extend? Extraterritorial Application of the European Convention on Human Rights. Journal of Transnational Law E Policy. Vol. 14.2, 2005. Pp. 159-215.

5. Al-Skeini and others v. The United Kingdom, No. 55721/07, para. 131, ECHR, 7 July 2011.

6. Assanidze v. Georgia [GC], No. 71503/01, $\S 139$, ECHR 2004 II.

7. Banković and others v. Belgium and Others (Decision as to admissibility), No. 52207/99, paras. 61, 67, ECHR, 12 December 2001;

8. Budzianovska D.C. Some reflections on the extraterritorial application of the European Convention of Human Rights. Wrozlav Review of Law Adminisration and Economics. Vol. 2:1, 2012. Pp. 51-60. URL: file://C:/Users/)/Downloads/ [20841264\%20-\%20Wroclaw\%20Review\%20of\%20 Law,\%20Administration\%20\&\%20Economics].pdf (дата звернення: 27.04.2020).

9. Caflisch L. Attribution, Responsibility and Jurisdiction in International Human Rights Law. Anuario Colombiano de Derecho 
Internacional. Vol. 10, 2017. URL: https://revistas. urosario.edu.co/xml/4295/429552542006/index. html (дата звернення: 27.04.2020).

10. Catan and Others v. the Republic of Moldova and Russia [GC], No. 43370/04, 8252/05 and 18454/06, ECHR, 19 October 2012.

11. Chiragov and Others v. Armenia [GC] No. 13216/05, ECHR, 16 June 2015.

12. Cyprus v. Turkey [GC], No. 25781/94, ECHR, 10 May 2001

13. Den Heijer M., Lawson R. Extraterritorial Human Rights and the Concept of "Jurisdiction". Global Justice, State Duties. The extraterritorial scope of economic, social and cultural rights in international law. Cambridge : Cambridge University Press, 2013. Pp. 153-191.

14. Duttwiler M. Authority, control and jurisdiction in the extraterritorial application of the European Convention on Human Rights. Netherlands Quarterly of Human Rights, Vol. 30/2, 2012. Pp. 137-162. URL: http://www.corteidh.or.cr/tablas/ r28821.pdf (дата звернення: 27.04.2020).

15. Eatwell T. States responsibility for human rights violations committed in the states territory by armed non-state actors. The Geneva Academy of International Humanitarian Law and Human Rights, Academy Breifing 13. URL: https://www.geneva-academy. ch/joomlatools-files/docman-files/Academy $\% 20$ Briefing\%2013.pdf (дата звернення: 27.04.2020).

16. European Convention for the Protection of Human Rights and Fundamental Freedoms, as amended by Protocols Nos. 11 and 14. Council of Europe, 4 November 1950, ETS 5. URL: https:// www.refworld.org/docid/3ae6b3b04.html (дата звернення: 26.04.2020).

17. Güzelyurtlu and Others v. Cyprus and Turkey, No. 36925/07, ECHR, 29 January 2019.

18. Ilascu and others v. Moldova and Russia, No. 48787/99, para. 312, ECHR, 8 July 2004.

19. Ivanțoc and Others v. Moldova and Russia, No. 23687/05, ECHR, 15 November 2011.
20. Loizidou v. Turkey (Article 50), No. 15318/89, ECHR, 28 July 1998.

21. Loizidou v. Turkey (merits), ECHR, 18 December 1996, Reports of Judgments and Decisions 1996-VI.

22. Loizidou v. Turkey (preliminary objections), No. 15318/89, ECHR, March 1995.

23. Milanovic M. Does the European Court of Human Rights Have to Decide on Sovereignty over Crimea? Part I: Jurisdiction in Article 1 ECHR. EJIL: TALK! Blog of the European Journal of International Law. September 23, 2019. URL: https://www. ejiltalk.org/does-the-european-court-of-humanrights-have-to-decide-on-sovereignty-over-crimeapart-i-jurisdiction-in-article-1-echr/ (дата звернення: 27.04.2020).

24. Milanovic M. Extraterritorial Application of Human Rights Treaties: Law, Principles, and Policy. Oxford University Press, 2011. Vol. 11. 304 p.

25. Miller S. Revisiting Extraterritorial Jurisdiction: A Territorial Justification for Extraterritorial Jurisdiction under the European Convention. European Journal of International Law. Volume 20. Issue 4. November 2009. Pp. 1223-1246.

26. Mozer v. the Republic of Moldova and Russia [GC], No. 11138/10, ECHR, 31 March 2010.

27. Obligation to respect human rights. Concepts of "jurisdiction" and imputability. Guide on Article 1 of the European Convention on Human Rights. Updated on 31 December 2019. Council of Europe/ European Court of Human Rights, 2020. P. 12, para. 30. URL: https://www.echr.coe.int/Documents/ Guide_Art 1_ENG.pdf (дата звернення: $25.04 .2020)$.

28.155 (1960). Resolution of 24 August 1960 S/4469. URL: http://unscr.com/en/resolutions/ $\mathrm{doc} / 155$ (дата звернення: 27.04.2020).

29. Sargsyan v. Azerbaijan [GC], No. 40167/06 paras. 14-28, ECHR, 14 December 2012.

30. Soering v. United Kingdom, No. 14038/88, para. 86, ECHR, 07 July 1989.

The article examines the practice of the European Court of Human Rights on the responsibility of the state for violations of the Convention for the Protection of Human Rights and Fundamental Freedoms of 1950 outside its national territory, namely - on the territory of another State Party to the Convention, by establishing, for the purposes of art. 1 of the Convention, such state's jurisdiction as a consequence of its effective control over this territory. Particular attention is focused on the cases (initiated both under Art. 33 and within the framework of Art. 34 of the Convention) concerning the creation (with military, economic or political support of a State Party to the Convention) on the internationally recognised territory of another State Party Convention (Cyprus, Moldova, Azerbaijan) of an entity, which is not recognized by the international community as a sovereign state: regarding Turkey's responsibility for breaches of the Convention in Northern Cyprus, Russia's responsibility for violations committed in Transdniestria, and Armenia's responsibility for violations in NagornoKarabakh.

An analysis of the Court's case-law on the responsibility of the state for the violation of the Convention by establishing, for the purposes of Art. 1 of the Convention, its jurisdiction over the internationally recognized territory of another State Party to the Convention has made it possible to identify a number of grounds on which the former may be held responsible in the Court for human rights violations in that territory. A key reason for establishing a state's jurisdiction for actions outside its national territory is to prove that it exercises effective control over a foreign territory - as a result of military (legal or illegal) actions: direct effective control - through the armed forces of that state, or indirectly - through its subordinate local administration. Establishing the fact of such a control over that territory puts on to the state, exercising it, the responsibility both for the actions of its soldiers or officials in the area and for the policies and actions 
of the local administration and eliminates the need to prove in the Court the fact of detailed control exercising over the policies and actions of the latter. In establishing the existence of effective control, the Court takes into account the number of soldiers deployed by the State in the territory in question and the extent to which the State's military, economic and political support for the local subordinate administration provides it with influence and control over the region.

Proving the fact of occupation of an internationally recognized territory of a State Party to the Convention by the armed forces of another Convention state and preventing them from exercising the rights and freedoms enshrined in the Convention may be the ground for entailing the jurisdiction under Art. 1 of the Convention of the latter. The overall and exclusive control over the occupied territory by the state can be confirmed by the fact that it dictates the course of events within its borders. If a local administration in such a territory survives as a result of the military, political, financial or other support of a foreign state, the jurisdiction of that state in that territory shall extend to the full range of substantive rights set out in the Convention and the additional protocols ratified by it and, correspondingly, it shall be responsible for their violation. The close relations of a State party to the Convention with an entity unrecognized by the international community after supporting its creation may be equated with the political, financial and economic support of the separatist regime. Involvement (by military presence and provision of military material and advice) of a State Party to the Convention at the early stages of a conflict in another State Party (based on its reports and public statements), which led to the creation of an entity that is not recognized by the international community in connection with the provision of significant political and financial support to the local administration of such an entity, at the expense of which the latter did survive, indicate the existence of effective control of such a state over its territory.

Key words: European Court of Human Rights, Convention, human rights violations, territory, jurisdiction, responsibility, Loizidou, Cyprus v. Turkey, Güzelyurtlu, Ilaşcu, Ivanţoc, Catan, Mozer, Chigarov. 